\title{
EFFECT OF STERCULIA FOETIDA BIODIESEL ON SINGLE CYLINDER FOUR STROKE DIESEL ENGINE PERFORMANCE AND EMISSIONS
}

\author{
Dr. P.P. Sethusundaram ${ }^{1}$, M.Vijayakumar ${ }^{2}$, N. Prasanna ${ }^{3}$ \\ ${ }^{1}$ Professor, Department of Mechanical Engineering, M.Kumarasamy College of Engineering, Karur, India. \\ Email: ppsethu63@yahoo.com \\ ${ }^{2}$ Assistant Professor, Department of Mechanical Engineering, M.Kumarasamy College of Engineering, Karur, \\ India. \\ Email: vijithermal@gmail.com \\ ${ }^{3}$ Assistant Professor, Department of Mechanical Engineering, Kongu Engineering College, Perundurai, Erode, \\ India. \\ Email: bemethermal@gmail.com
}

\begin{abstract}
In the present work, transesterified new biodiesel of sterculia foetida oil is mixed with diesel and the engine performance, combustion and emission was analysed. The primary objective work is to produce a new alternate and biodegradable fuel for compression ignition engine. The biofuel oil is an extract from sterculia foetida seed and transesterfied with $20 \%$ methanol and $2 \% \mathrm{KOH}$. The transesterfied biofuel concentrations were varied at $25 \%, 50 \%, 75 \%$ and 100\% with diesel viz. B25, B50, B75 and B100. The engine is operated at different load conditions with different concentration of fuel. The experiments are conducted and the fuel blend B25 produces maximum of brake thermal efficiency in comparison with other biodiesel blends and produced maximum heat release and minimum emission produced at B25 biodiesel blend.
\end{abstract}

\section{Indexing terms/Keywords}

Compression ignition engine, Sterculia foetida oil blends, Performance, Combustion parameters

\section{Academic Discipline and Sub-Disciplines}

Bio fuel, Transesterification

\section{SUBJECT CLASSIFICATION}

Alternative fuels

\section{TYPE (METHOD/APPROACH)}

\author{
Experimental Study
}

\section{INTRODUCTION}

Producing and using bio fuels for transportation offer an alternative to fossil fuels and they can help provide solutions to many environmental problems. The recent commitment of many countries to increase bio energy has added an impetus to the search for viable bio fuels [1]. Methanol and ethanol are two viable alternative fuels which possess the potential to be produced from biomass sources. Neither of the fuels are well suited for use in diesel engines, and the use of high compression ratios, ignition improve and the ignition assistance devices are very common [2,3]. Normally, three types of catalysts, such as a strong alkali, a strong acid or an enzyme, can be used in the manufacturing process of the transesterification method. Almost all biodiesel fuels are produced by using base catalyzed transesterification process, as it is a simple process requiring only a low temperature [4], shorter reaction time and less amount of required catalyst [5]. Hence, the strong alkali catalyst is widely used in the transesterification process to produce biodiesel. $\mathrm{NaOH}$, due to its low cost, is widely used in a large scale transesterification [6]. Methanol is used mostly in this chemical reaction due to its superior advantages of high solubility in oil, fast reaction rate, good physical and chemical properties, and low cost [7-9]. Two step process of producing biodiesel from pungamia pinnata oil was studied and the effect of FFA level on the production of biodiesel was also studied. Ester content of pungamia methyl esters was determined by high performance liquid chromatography [10]. The another important transesterification method studied from waste fryer grease (WFG) containing 5-6 wt.\% free fatty acid (FFA) which was carried out with methanol, ethanol and the mixtures of methanol or ethanol maintained the oil to alcohol molar ratio of 1:6 and initially with $\mathrm{KOH}$ as a catalyst. Transesterification of vegetable oil to biodiesel fuel using alkaline catalyst was also referred $[11,12]$. The biodiesel blending ratio was decided from an experimental study with olive oil in DI and IDI engines. They have used 25:75 and 50:50 blends of transesterified olive oil and diesel fuel and observed slightly increased SFC [13] and another Bioblends used soyabean and sunflower oil in a $25 \%$ blend with petroleum diesel fuel [14]. Engine performance evaluation of DI and IDI engines with JME [15] and calculated the heat release rate for rapeseed methy ester (RME) and higher biodiesel combustion rate was observed [16]. The combustion characteristics of neat animal fat, animal fat emulsion with ethanol and water are compared with diesel fuel [17]. The performance of jatropha curcas oildiesel blends in $\mathrm{Cl}$ engine was observed and reduced the raw oil viscosity by blending with diesel. The biodiesel - diese blends properties are varied from edible and non-edible oil feedstock [18] and an investigation of milkweed (asclepias) 
seed oil as an alternative feedstock for the production of a biodiesel fuel was also studied. The authors concluded that conversion of this highly unsaturated oil into methyl ester is an easier process than its conversion into its ethyl ester [19].

\section{MATERIALS AND METHODOLOGY}

\subsection{Sterculia Foetida}

Sterculia foetida trees, fruits and seeds are shown in Fig.1. Normally, sterculia foetida has Grayish - white bark and reddish fruits. The flowers are 5 lobed green yellowish when they release and soon after turn deep reddish. The red fruits consist of 1 to 5 spreading follicles that are prepared with rigid stinging bristles along the inside margins. Each follicle splits to expose up to 17 black - blue seeds attached to the internal margins.

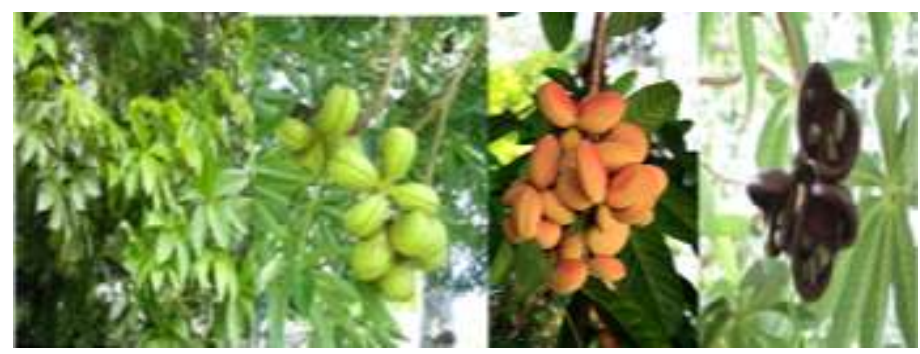

Fig.1. Sterculia foetida tree and fruits with seed

\subsection{Extraction of Oil}

Before extraction Sterculia foetida oil obtained from sterculia foetida seed have to be washed by water and dried under sunlight. The extraction of crude sterculia foetida oil was done by cutting machine (Heard cell are broken) and then crushed in a expeller machine. During the crushing in the machine, some sugar wastes are added to get maximum amount of oil in the crushing. Fig.2. shows the different preparatory stages of seed before crushing.

\subsection{Fatty acid composition}

Sterculia foetida oil fatty acid level is shown in Fig.4. Raw sterculia foetida oil has maximum percentage of palmitic content, its contribution to the combustion of the oil was also significant level. Oleic acid with a single bound and saturation level contributed enormously to the performance of the fuel [20]. Linoleic is unsaturated - it has $20.9 \%$ of sterculia foetida with higher oxygen rate to oxidation process. The fatty acid level is clearly mentioned in Table 1.

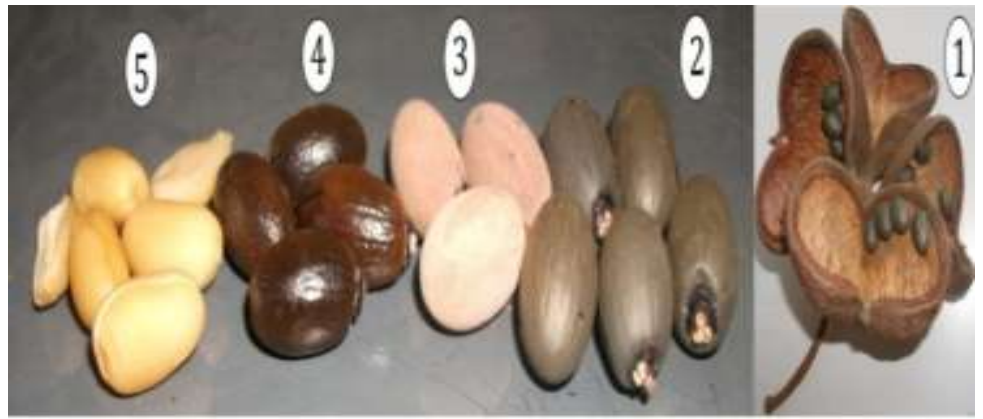

Fig.2. Different stages of seed preparations

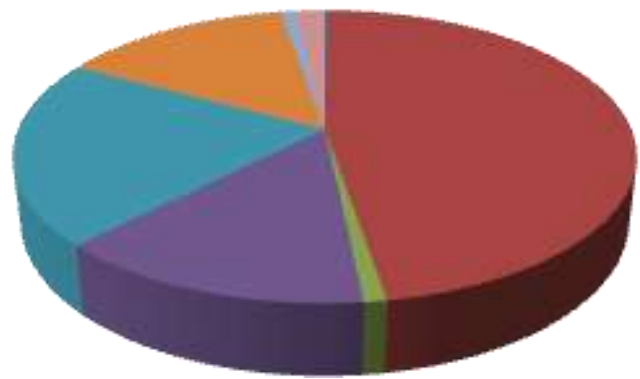

$$
\begin{aligned}
& \square 1 \text { Myristic } \\
& \square 3 \text { Stearic } \\
& \square 5 \text { Linoleic } \\
& \square \text { Arachidic }
\end{aligned}
$$

$$
\begin{aligned}
& =2 \text { Palmitic } \\
& 4 \text { Oleic } \\
& -6 \text { Linoleni } \\
& -8 \text { Unsaponifiable matter }
\end{aligned}
$$


Fig.3. Fatty acid composition of sterculia foetida

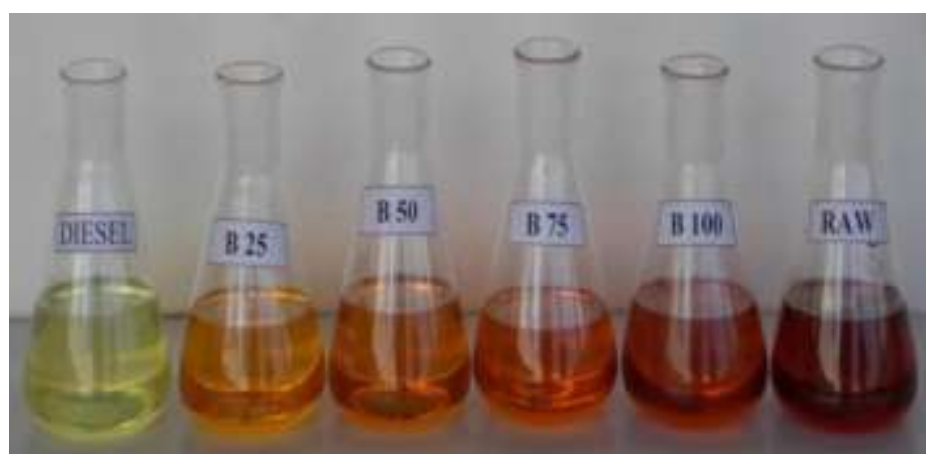

Fig.4. Different blend ratios of biodiesel

\subsection{Transesterification of Sterculia foetida oil}

Sterculia foetida oil was mixed with $15 \%$ of methanol and $2 \%$ of $\mathrm{KOH}$ catalyst. Electrical motor running at 200 rpm is used to agitate the solution. Reactor temperature is maintained at $55^{\circ} \mathrm{C}$, in this process continuously up to 6 hours. During the process one small drop (0.5\%) of sulfuric acid was added with the solution. After the treatment the solution is kept in rest position for 5 hours in normal temperature. Finally by products like glycerol and soap were separated. Then, the produced biodiesel was washed with water, two times in a separation funnel. Fig 5 shows different concentration of biodiesel with diesel fuel. The final flask is non esterified sterculia foetida oil.

\subsection{Experimental procedure}

In this experimental investigation, four strokes, single cylinder, water cooled, direct injection constant speed (1500), naturally aspirated VCR kirloskar made diesel engine is used. Engine cylinder bore of $87 \mathrm{~mm}$ and stroke of $110 \mathrm{~mm}$; the compression ratio of $15: 1$ to $18: 1$ and manufacture's recommended injection timing and injection pressure of $23^{\circ}$ crank angle before TDC and 201 bar respectively are taken. Further, 1500 engine rpm and 17:1 compression ratio are considered.

\subsection{Data Acquisition System}

The cylinder pressure at each crank angle is measured and stored by a digital data acquisition system. It consists of a Kistler water-cooled flush mounted piezoelectric pressure transducer in conjunction with Kistler charge amplifier for converting the electric charge into voltage. It measures and stores up to 200 cycles engine pressure histories. The measured data is analyzed with the online data or stored for post - processing.

Table 1. The bio diesel blending ratio

\begin{tabular}{|l|l|l|}
\hline Blend & Diesel \% & Biodiesel \% \\
\hline D100 & 100 & 0 \\
\hline B25 & 75 & 25 \\
\hline B50 & 50 & 50 \\
\hline B75 & 25 & 75 \\
\hline B100 & 0 & 100 \\
\hline
\end{tabular}

\section{RESULTS AND DISCUSSIONS}

The discussion of the results and interpretation of diesel and Sterculia foetida biodiesel blend on diesel engine performance, combustion and emission. The engine maximum load was calculated and it was applied $20 \%, 40 \%, 60 \%$, $80 \%$ and $100 \%$ and the biodiesel blend was prepared with diesel like B25, B50, B75, and B100. 


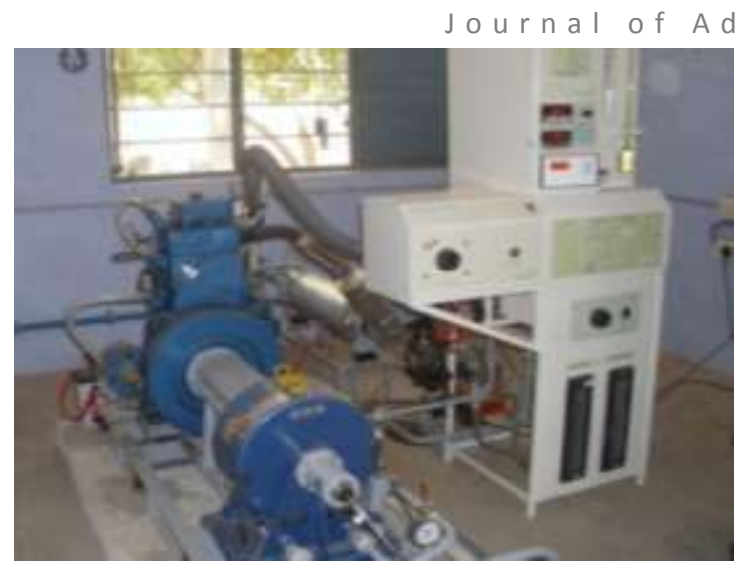

Fig.5. Experimental setup

\subsection{Brake Thermal Efficiency and Specific fuel consumption}

Fig 6 point up the brake thermal efficiency (BTE) of different biodiesel blends with different load conditions. The engine brake thermal efficiency increases with increasing engine load. Fig 7 shows the specific fuel consumption (SFC) of different biodiesel blend with different loading conditions. The SFC decreases with increasing engine load. Comparing these two results, the diesel fuel produced effective power in diesel engine compare with biodiesel blends. Biodiesel B25 blend consumed minimum fuel and produced same power which is produced by diesel. The SFC values of biodiesel higher than the diesel owing to the lower calorific values of biodiesel. More biodiesel was required to produce same power output owing to higher viscosity, poor air fuel mixing, higher volatility and calorific value. The higher viscosity gives impact on fuel spray characteristics.

\subsection{Combustion Analysis}

Fig 8 shows the maximum heat release with different biodiesel blend. The diesel fuel produced maximum heat release. The maximum heat release decreases with increasing biodiesel concentration. It was indicated that the lower calorific values of biodiesel and ignition delay. Fig 9 shows that the maximum heat release rate of diesel and different biodiesel blends. It is clearly indicated that the diesel fuel produced maximum heat release rate compare with biodiesel blend. These results are clearly indicated the effect of combustion. B25 heat release rate noted as second maximum heat release rate. The biodiesel concentration increases the heat release rate also decreasing due to low calorific values and poor atomization characteristics. Fig 10 shows the maximum cylinder pressure of different biodiesel concentration. The diesel fuel produced minimum cylinder pressure and entire biodiesel blend produced maximum cylinder pressure at maximum load. The fig 8, 9 and 10 clearly indicated the suitable biodiesel blend. B25 produced maximum heat release and maximum cylinder pressure compare with other biodiesel blend.

\subsection{Emission analysis}

Normally the $\mathrm{HC}, \mathrm{CO}, \mathrm{CO} 2, \mathrm{NOx}$, and smoke pollutants consider primarily in the internal combustion engine emissions. Engine load increases with increasing engine exhaust gas temperature. Fig 11 shows that the diesel fue produced maximum exhaust gas temperature at entire engine load due to higher heat release in diesel fuel it's clearly indicated in fig 8. Normally the $\mathrm{HC}, \mathrm{CO}, \mathrm{CO} 2, \mathrm{NOx}$, and smoke pollutants are considered primarily in the internal combustion engine emissions. Engine load increases with increasing engine exhaust gas temperature. Fig 11 shows that the diesel fuel produced maximum exhaust gas temperature at entire engine load due to higher heat release in diesel fuel it's clearly indicated in fig 8 . Fig 12 shows that the $\mathrm{CO}$ for diesel and different blend of biodiesel with different engine load. The entire biodiesel blend produced maximum CO compare with base diesel fuel. The biodiesel concentration causes to increase the CO pollutant.

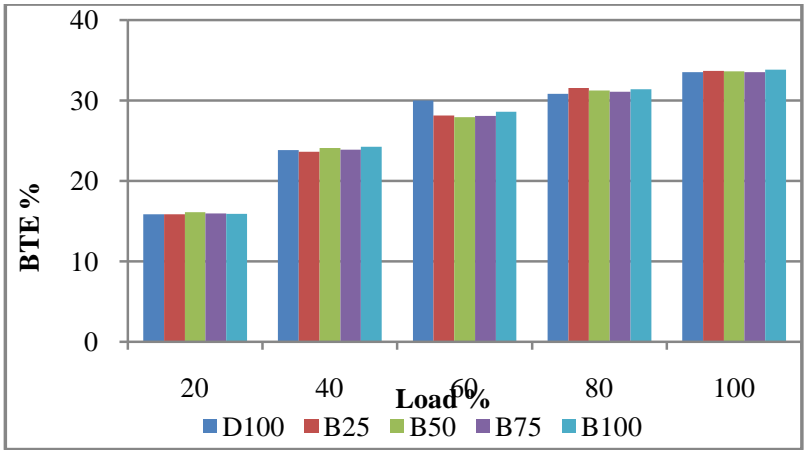

Fig.6. Brake thermal Efficiency for different biodiesel concentration with different load 


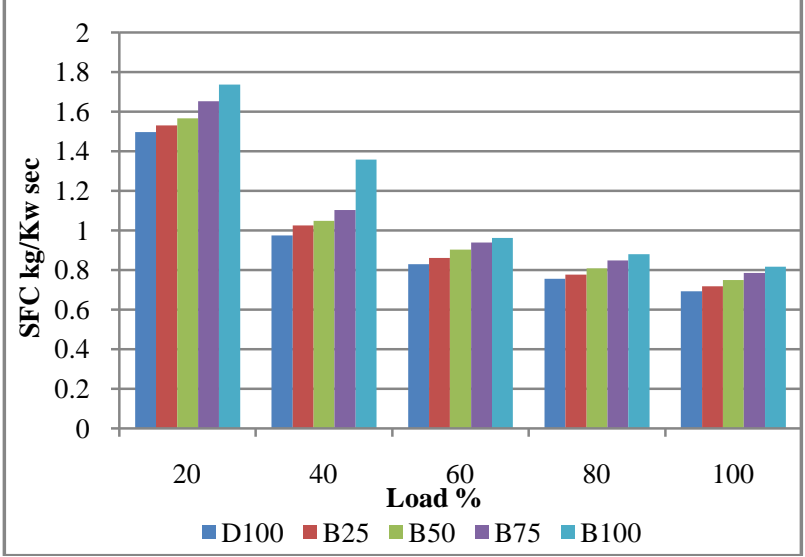

Fig.7. Specific fuel consumption for different biodiesel concentration with different load

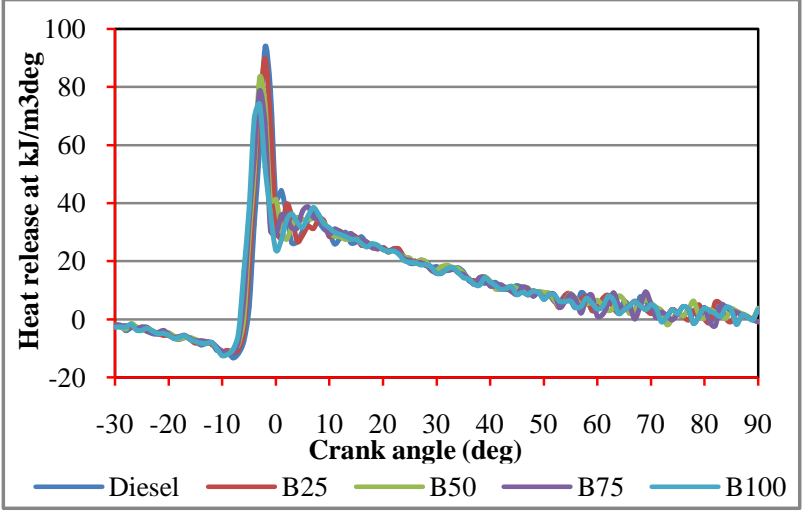

Fig.8. Maximum heat release with crank angle for different biodiesel concentration

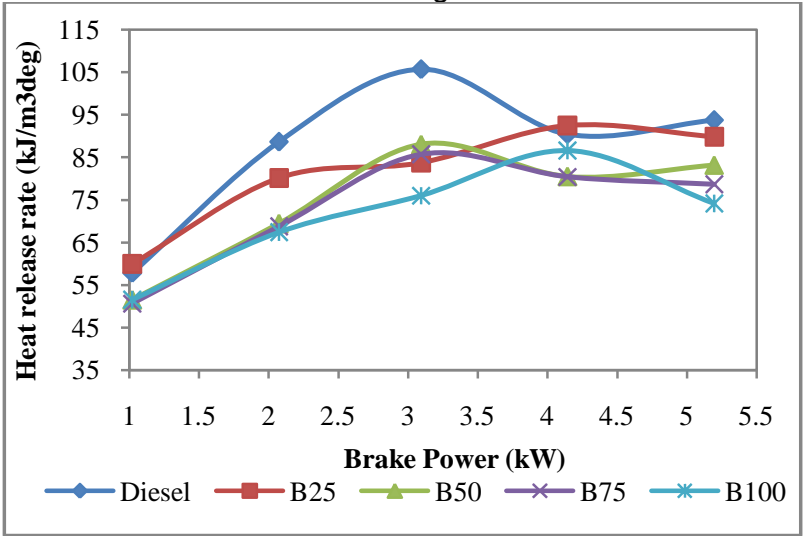

Fig.9. Heat release rate for different biodiesel concentration with different brake power

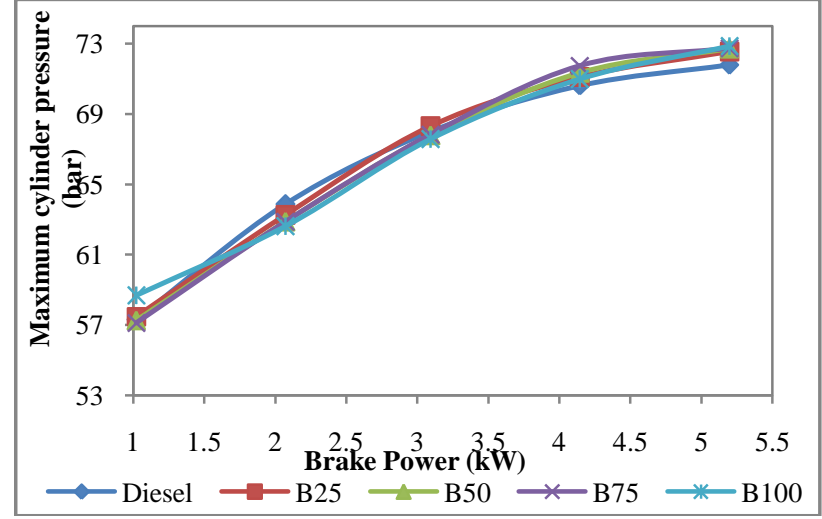

Fig.10. Maximum cylinder pressure for different biodiesel concentration with brake power 


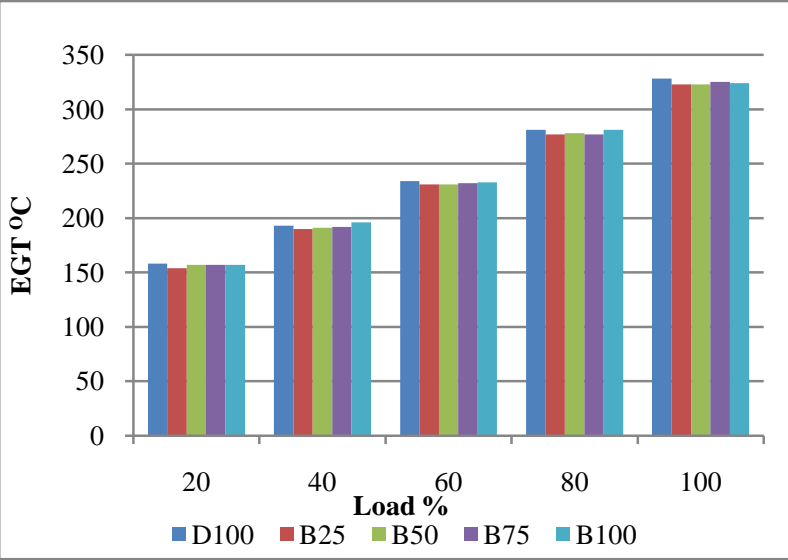

Fig.11. Exhaust gas temperature for different biodiesel concentration with different load

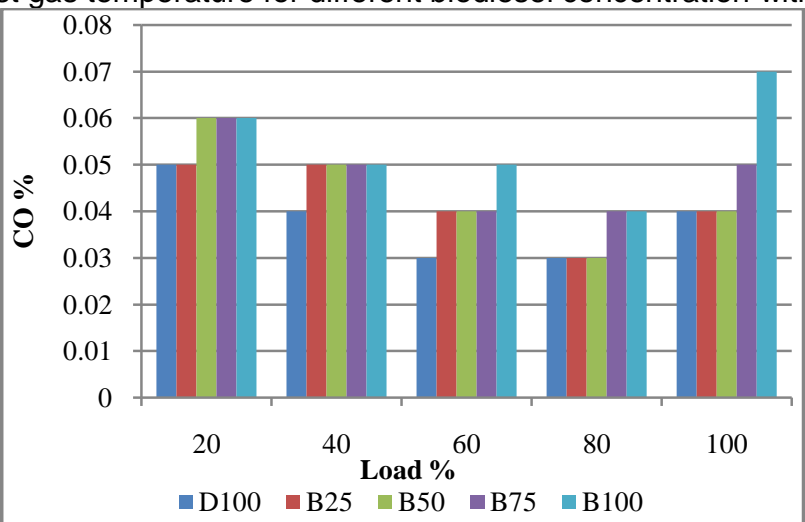

Fig.12. Carbon monoxide for different biodiesel concentration with different load

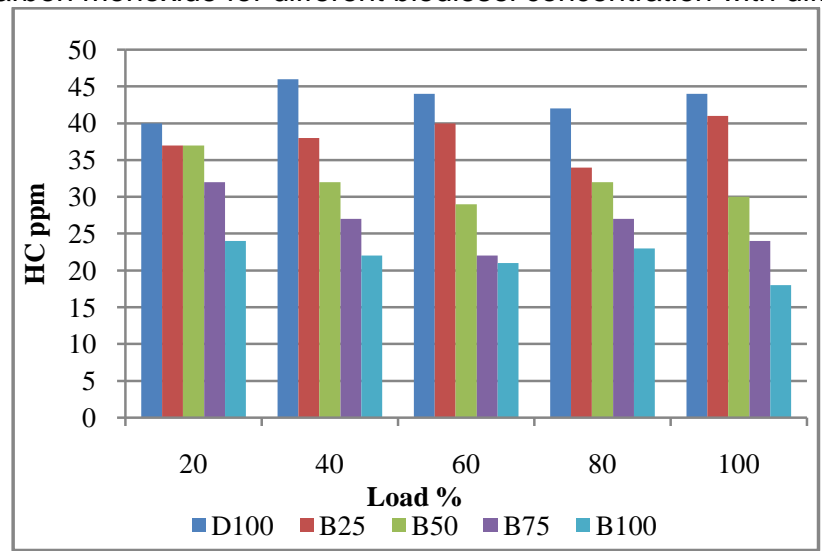

Fig.13. Unborn hydrocarbon for different biodiesel concentration with different load

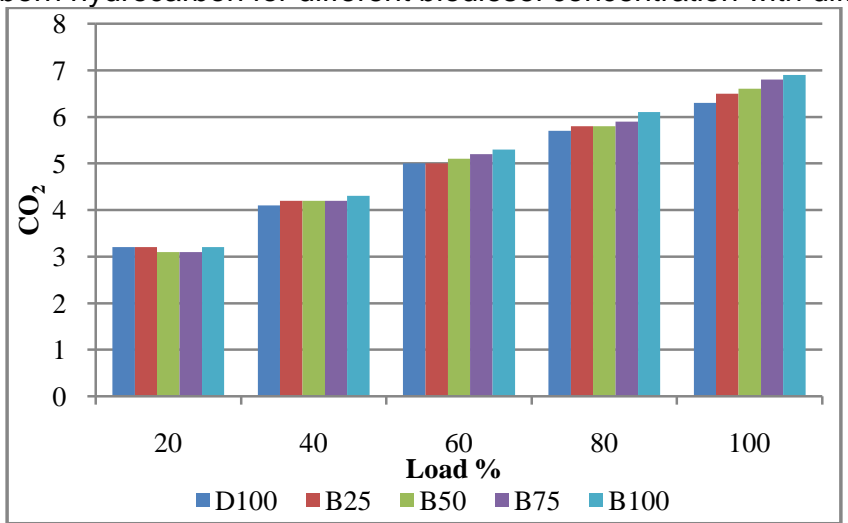

Fig.14. Carbon dioxide for different biodiesel concentration with different load 


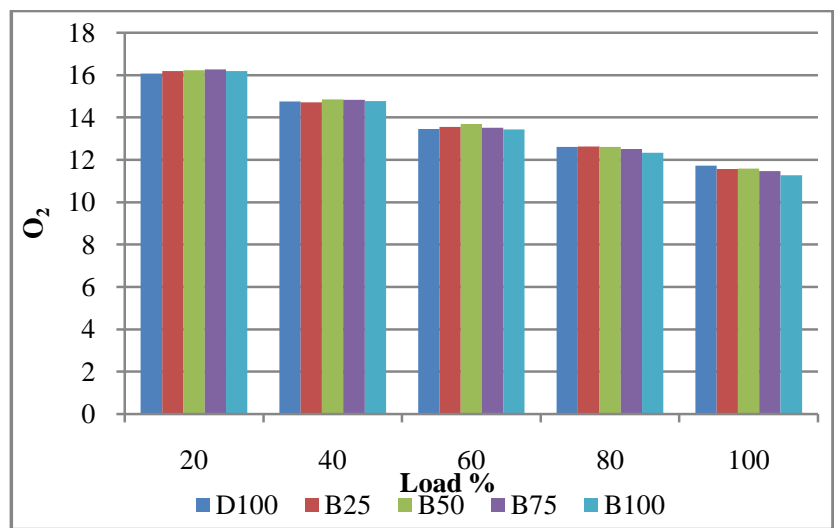

Fig.15. Excess Oxygen for different biodiesel concentration with different load

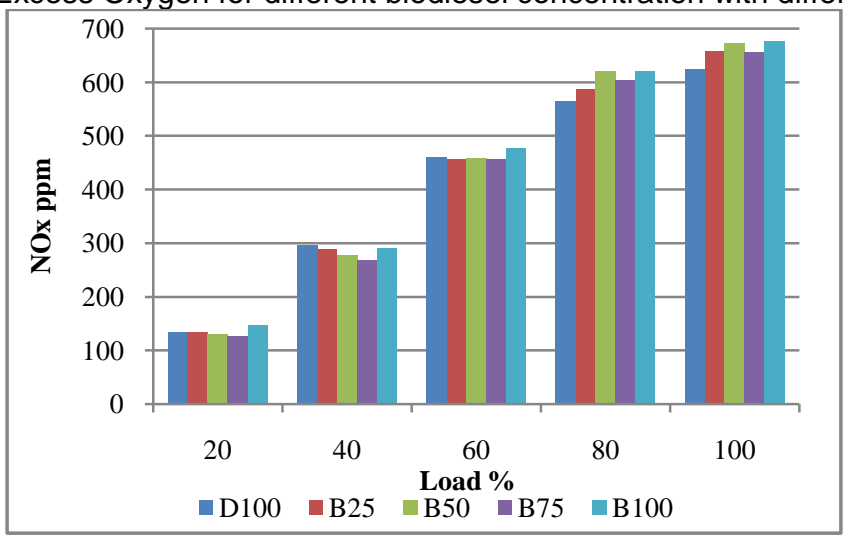

Fig.16. Nitrous oxide for different biodiesel concentration with different load

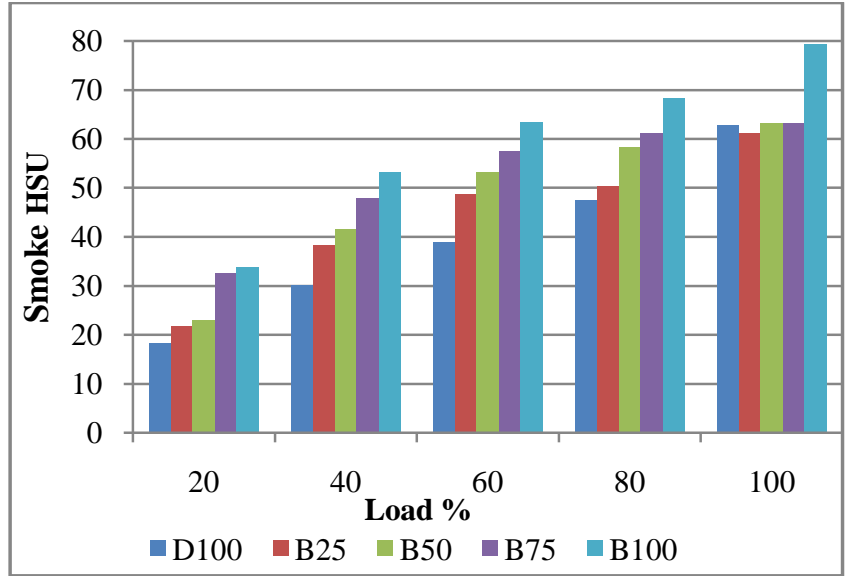

Fig.17. Nitrous oxide for different biodiesel concentration with different load

The higher $\mathrm{CO}$ in the engine exhaust gas of the fuel may be endorsed to the fuel spray system. Biodiesel has higher viscosity compare with diesel. In this viscosity reduces the injection system penetration rate and atomization process. The biodiesel is not easy to mixing with air it cause to create locally rich mixture. Fig 13 shows that variation of HC for different biodiesel concentration with different engine load. The maximum HC notified with base diesel fuel at entire engine load. It does clearly explain the incomplete combustion. Fig 14 shows that the $\mathrm{CO}_{2}$ pollutant production. $\mathrm{CO}_{2}$ level increases with increasing engine load. The $\mathrm{B} 25$ produced minimum $\mathrm{CO}_{2}$ level in the biodiesel blend. Fig 15 shows the excess oxygen level. Excess oxygen level decreases by increasing engine load and decreasing $\mathrm{CO}_{2}$ level. Equation 1 indicates the chemical reaction of $\mathrm{CO}_{2}$ formation that the $\mathrm{CO}$ react with $\mathrm{O}_{2}$ its gives $\mathrm{CO}_{2}$.

Fig 16 shows the NOx variation of different biodiesel blend. B25 produced minimum NOx compare with other biodiesel blend except $20 \%$ and $40 \%$ load. Prompt mechanisms and fuel NOx mechanism mainly consider for NOx production owing to incomplete combustion. Fig 17 shows that the smoke pollutant. Smoke density increases with increasing engine load as well as biodiesel concentration. That result shows that B25 blend produced minimum smoke density compare with other biodiesel blend.

Fig 12 shows that the $\mathrm{CO}$ for diesel and different blend of biodiesel with different engine load. The entire biodiesel blend produced maximum CO compare with base diesel fuel. The biodiesel concentration causes to increase the $\mathrm{CO}$ pollutant. The higher $\mathrm{CO}$ in the engine exhaust gas of the fuel may be endorsed to the fuel spray system. Biodiesel has 
higher viscosity compare than diesel. In this viscosity reduces the injection system penetration rate and atomization process. The biodiesel is not easy to mixing with air it cause to create locally rich mixture.

Fig 13 shows that variation of $\mathrm{HC}$ for different biodiesel concentration with different engine load. The maximum HC notified with base diesel fuel at entire engine load. It does clearly explain the incomplete combustion. Fig 14 shows that the $\mathrm{CO} 2$ pollutant production. CO2 level increases with increasing engine load. The B25 produced minimum $\mathrm{CO} 2$ level in the biodiesel blend. Fig 15 shows the excess oxygen level. Excess oxygen level decreases with increasing engine load. Excess oxygen level decrease $\mathrm{CO} 2$ level increases because $\mathrm{CO}$ react with oxygen its gives $\mathrm{CO} 2$.

Fig 16 shows the NOx variation of different biodiesel blend. B25 produced minimum NOx compare with other biodiesel blend except $20 \%$ and $40 \%$ load. Prompt mechanisms and fuel NOx mechanism. Fig 17 shows that the smoke pollutant. Smoke density increases with increasing engine load as well as biodiesel concentration. That result shows that B25 blend produced minimum smoke density compare with other biodiesel blend.

\section{CONCLUSION}

In this investigation, the differ

$$
\mathrm{CO}+\mathrm{O} 2 \longrightarrow \mathrm{CO} 2
$$
to analyze the engine performance, combustion and emission analysis. The different biodiesel blends supplied with different engine load. drawn:

On comparing the performance, combustion and emission of different biodiesel blends with different engine load were

- $\quad$ Compare BTE and SFC values of B25 closer to the base diesel fuel results

- $\quad$ B25 produced maximum heat release and maximum cylinder peak pressure compare with other biodiesel blends

- The maximum HC produced in B25 fuel compare with all other biodiesel blend.

- $\quad \mathrm{CO}, \mathrm{CO} 2, \mathrm{NOx}$, smoke produced minimum level in B25 fuel compare with all other blends

It is concluded that maximum effective power and minimum pollutant produced only in B25 fuel. B25 blend consider for future research to develop biodiesel engine. Sterculia foetida is a one type of tree. Tree cultivation is simple to collects the bulk volume of seeds. In future sterculia foetida seeds biodiesel production is effortless and very effective for diesel engine operations without any modifications in the engine.

\section{REFERENCE}

1. Demirbas A. 2008 "Biofuels sources, biofuel policy, biofuel economy and global biofuel projections". Energy Conversion Management; 49: 2106-16.

2. McCormick RL, and Parish R. 2001 "Technical barriers to the use of ethanol in diesel fuel". Milestone report to NREL/MP 540-32674.

3. Hansen AC, Lyne PWL, Zhang Q.2001 "Ethanol - diesel blends; A. step towards a bio-based fuel for diesel engines". SAE paper 2001-01-6048.

4. Ma MA, Hanna. 1999 Biodiesel Production: A Review. Bio resource Technology: 70:1-15.

5. Lin CY, Lin HA. 2006 "Diesel engine performance and emission characteristics of biodiesel produced by the peroxidation process". Fuel; 85: 298-305.

6. Agarwal D, Agarwal AK. 2007 "Performance and emissions characteristics of jatropha oil (preheated and blends) in a direct injection compression ignition engine". Applied Thermal Engineering; 27:2314-23.

7. Korbitz W. 2000 "Biodiesel production in Europe and North America, an encouraging prospect". Renewable Energy; $16: 1078-83$.

8. Nagaraja AM, Kumar GP. 2004 "Characterization and optimization of rice bran oil methyl ester for CI engines at different injection pressures". SAE paper 2004-28-0048.

9. Sinha S, Agarwal AK. 2005 "Performance evaluation of a biodiesel (rice bran oil methyl ester) fuelled transport diesel engine". SAE paper 2005-01-1730.

10. Malaya Naik, Meher LC, Naik SN, Das LM. 2008 "Production of biodiesel from high free fatty acid Karanja (Pongamia Pinnata) oil". Biomass and Bioenergy; 32:354-57.

11. Pramanik K. 2003 "Properties and uses of Jatropha curcas oil and diesel fuel blends in compression ignition engine". Renewable energy; 28: 239-48.

12. Keera ST, El Sabagh SM, Taman AR. 2011 "Transesterification of vegetable oil to biodiesel fuel using alkaline catalyst". Fuel;90: 42-7.

13. Rakopoulos CD, Hountalas DT, Rakopoulos DC, Giakoumis EG. 2005 "Experimental heat release rate analysis in both chambers of an indirect injection turbocharged diesel engine at various load and speed conditions". SAE paper 2005-01-0926.

14. Schlick ML, Hanna MA, Schinstock JL. 1986 "Soybean and sunflower oil performance in a diesel engine". ASAE paper 1986-86-3068. 
15. Rao GAP, Mohan PR. 2005 "Performance evaluation of DI and IDI engines with Jatropha oil based biodiesel". Journal of Institute of Engineers (India); 86:72-76.

16. Grimaldi CN, Lucio Postrioti, Michele Battistoni Federico Millo. 2002 "Common rail HSDI diesel engine combustion and emissions with fossil/Bio-derived fuel blend". SAE paper 2002-01-0865.

17. Senthil kumar M, Karihuel A, Bellettre J, Tazerout M. 2006 "Ethanol animal fat emulsion as a diesel engine fuel- Part 2: Engine test analyses". Fuel; 85: 2646-52.

18. Silitonga AS, Masjuki HH, Mahlia TMI, Ong HC, Chong WT. 2013 "Overview properties of biodiesel diesel blends from edible and non-edible feedstock". Renew Sust Energy Rev;22: 346-6.

19. Holser RA, Kuru RH. (2006) "Transesterified Milkweed (asclepias) seed oil as a biodiesel fuel”. Fuel; 85:20162110.4.

20. Oseni MI, Obetta SE, Orukotan FV 2012. "Evaluation of fatty acids profile of ethyl esters of yellow oleander and groundnut oils as biodiesel feedstock". American journal of scientific and industrial research; 3: 62-68.

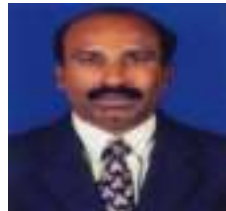

P.P.Sethusundaram was born in Tamilnadu, India in 1963. He received Master's degree in Thermal Power Engineering at Annamalai University, Chidambaram, Tamilnadu, India in 1988 and Ph.D in Anna University, Chennai, India in 2014. His research interest includes heat storage and internal combustion engine. He is working as Professor in Mechanical Engineering, M.Kumarasamy College of Engineering, Thalavapalayam, Karur-639113, Tamil Nadu, India.

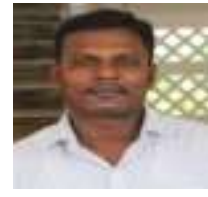

M.Vijayakumar was born in Tamilnadu, India in 1986. He received Master's degree in Thermal Engineering at Anna University (BIT campus) Chennai, Tamilnadu, India in 2014 and doing Ph.D in Anna University Chennai, India. His research interest includes heat storage and thermal energy tranformation. He is working as Assistant Professor in Mechanical Engineering, M.Kumarasamy College of Engineering, Thalavapalayam, Karur-639113, Tamil Nadu, India.

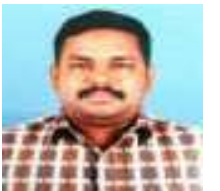

N.Prasanna was born in Tamilnadu, India in 1986. He received Master's degree in Thermal Engineering at saranathan college of engineering under anna university chennai, Tamilnadu, India in 2015. His research interest includes Solar energy utilization and cyclone separator. He is working as Assistant Professor in Mechanical Engineering, Kongu engineering college, Perundurai- 638052, Tamil Nadu, India. 